\title{
Statistical Analysis for Usability Evaluation of Unmanned Aerial Vehicle in Geomatics
}

\author{
Joon Kyu Park, ${ }^{1}$ Kap Yong Jung, ${ }^{2 *}$ and Joong Hyeok Heo ${ }^{3}$ \\ ${ }^{1}$ Department of Civil Engineering, Seoil University, 28, Yongmasan-ro 90-gil, Jungnang-gu, Seoul, Korea \\ ${ }^{2}$ Department of Construction Engineering Education, Chungnam National University, \\ 99 Daehak-ro, Yuseong-gu, Daejeon, Korea \\ ${ }^{3}$ Department of Geosciences, University of Texas Permian Basin, 4901 East University, Odessa, Texas, USA
}

(Received April 26, 2020; accepted June 24, 2020)

Keywords: accuracy, meta-analysis, geospatial information, statistical analysis, unmanned aerial vehicle

Unmanned aerial vehicles (UAVs) have advantages such as a relatively low operating cost and excellent ground-sample distance (GSD) compared with conventional manned aerial photogrammetry. Recently, the development of sensor technology has enabled digital mapping, terrain model generation, economic evaluation, monitoring, cadastral surveying, coastal surveying, and ground surveying. However, existing studies have shown the limited validity of UAVs for spatial information construction owing to limited experiments and analyses. In this study, the validity of UAVs for spatial information construction was evaluated, and recent case studies related to the accuracy of the results were analyzed. The results of 34 studies including quantitative results of UAV accuracy within the last 5 years were investigated, and the correlations of flight altitude, accuracy, and ground control point (GCP) number are presented through the analyses of existing studies. The horizontal and vertical accuracies of terrain information using a UAV were $0.51 \mathrm{~m}$ and $0.56 \mathrm{~cm}$, respectively. The horizontal and vertical accuracies were correlated with the flight altitude and GCP number, with the flight altitude having a greater effect than the GCP number. In the future, the results of this study will be used as a basis to examine the validity of geospatial information construction using a UAV.

\section{Introduction}

Recently, many studies related to unmanned aerial vehicles (UAVs) have been conducted owing to the development of information communication technology and sensor technology. ${ }^{(1,2)}$ In addition, as map information and location services provided through various media such as smartphones, Internet portals, and navigation software are popularized, the application of unmanned airplanes is increasing as an efficient method of constructing geospatial information. $^{(3,4)}$ UAVs can shoot at a low altitude as compared with conventional manned aerial photogrammetry, so they can be applied even in slightly cloudy weather, have a relatively low operating cost, and have an excellent ground-sample distance (GSD). ${ }^{(5,6)}$ Recent studies related to UAVs have been applied to a variety of fields, such as digital mapping, terrain model

*Corresponding author: e-mail: jungjusa@hanmail.net https://doi.org/10.18494/SAM.2020.2912 
generation, economic evaluation, monitoring, and current surveying. ${ }^{(2,7)}$ However, existing studies are mainly limited to experiments and analyses of specific applications. Therefore, the statistical validity of presenting the characteristics of geospatial information using a UAV is not high, so an integrated analysis of the results of previous research is needed. In this study, recent papers related to UAVs were examined, and a meta-analysis was conducted on the results of these studies. Figure 1 shows the flow of this study.

\section{Selection of Articles for Analysis}

The amount of UAV-related research studies has been increasing recently owing to the development and distribution of commercial UAVs. Starting from the development of systems in the early 2000s, research has been conducted on calculating the output and the accuracy of verification for application to various fields. ${ }^{(8,9)}$ In this study, a literature survey was conducted for research within the last 5 years using the National Research Foundation of Korea website to select the studies to be analyzed. A total of 11297 articles using "UAV" as a keyword were found through a website survey, and 34 of the articles from the last 5 years related to "Accuracy" were selected. Table 1 shows the selected articles.

The recently published UAV-accuracy-related research studies were carried out on a variety of topics, such as cartography, terrain model generation, and spatial analysis. In most of these studies, the accuracy of the UAV results was verified to determine the validity and usability. In this study, a comprehensive analysis was carried out on the studies that included quantitative results on the degree of purification in the existing studies.

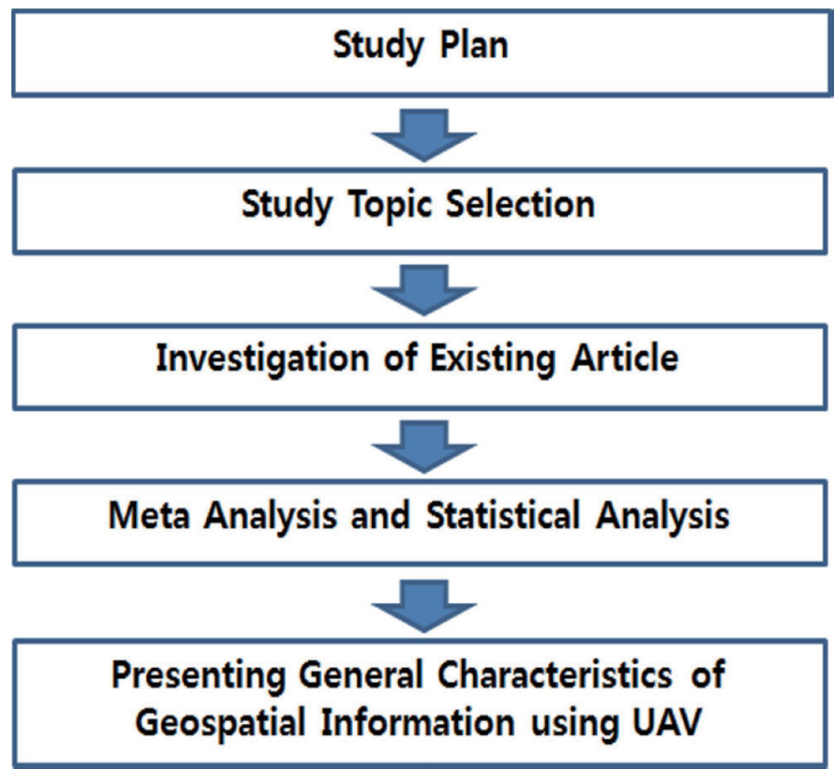

Fig. 1. (Color online) Study flow. 
Table 1

Selected articles.

\begin{tabular}{|c|c|c|c|}
\hline No. & Title & Year & Journal \\
\hline 1 & $\begin{array}{l}\text { Accuracy Evaluation and Terrain Model Creation of Urban Space Using Unmanned } \\
\text { Aerial Vehicle System }\end{array}$ & 2018 & $\begin{array}{l}\text { Journal of the Korea Institute of Intelligent Transportation } \\
\text { Systems }\end{array}$ \\
\hline 2 & $\begin{array}{l}\text { A Study on Landscape Management Techniques of Cultural Heritage Designated } \\
\text { Area Using 3D Mapping Method }\end{array}$ & 2018 & $\begin{array}{l}\text { Journal of the Korean Institute of Traditional Landscape } \\
\text { Architecture }\end{array}$ \\
\hline 3 & Digital Map Updates with UAV Photogrammetric Methods ${ }^{(10)}$ & 2015 & $\begin{array}{l}\text { Journal of the Korean Society of Surveying, Geodesy, } \\
\text { Photogrammetry and Cartography }\end{array}$ \\
\hline 4 & $\begin{array}{l}\text { Assessment of Positioning Accuracy of UAV Photogrammetry Based on RTK- } \\
\text { GPS }^{(11)}\end{array}$ & 2018 & $\begin{array}{l}\text { Journal of the Korea Academia-Industrial Cooperation } \\
\text { Society }\end{array}$ \\
\hline 5 & $\begin{array}{l}\text { A Study on Utilization of 3D Shape Pointcloud Without GCPs Using UAV } \\
\text { Images }^{(12)}\end{array}$ & 2018 & $\begin{array}{l}\text { Journal of the Korea Academia-Industrial Cooperation } \\
\text { Society }\end{array}$ \\
\hline 6 & $\begin{array}{l}\text { A Study of Three-Dimensional DSM Development Using Self-Developed } \\
\text { Drone }^{(13)}\end{array}$ & 2018 & Journal of Korean Earth Science Society \\
\hline 7 & Efficient Extraction of Road Cross Section Using a UAV ${ }^{(14)}$ & 2018 & $\begin{array}{l}\text { Journal of the Korean Society for Geospatial Information } \\
\text { Science }\end{array}$ \\
\hline 8 & $\begin{array}{l}\text { Utilization Evaluation of Digital Surface Model by UAV for Reconnaissance } \\
\text { Survey of Construction Project }{ }^{(7)}\end{array}$ & 2018 & $\begin{array}{l}\text { Journal of the Korea Academia-Industrial Cooperation } \\
\text { Society }\end{array}$ \\
\hline 9 & Accuracy Analysis According to the Number of GCP Matching ${ }^{(15)}$ & 2018 & $\begin{array}{l}\text { Journal of the Korean Association of Geographic } \\
\text { Information Studies }\end{array}$ \\
\hline 10 & $\begin{array}{l}\text { Accuracy Analysis According to GCP Layout Type and Flying Height in } \\
\text { Orthoimage Generation Using Low-cost UAV } \\
\end{array}$ & 2018 & $\begin{array}{l}\text { Journal of the Korean Society for Geospatial Information } \\
\text { Science }\end{array}$ \\
\hline 11 & $\begin{array}{l}\text { Generation and Comparison of Orthophotos and 3D models of Small-scale } \\
\text { Terraced Topography using Vertical and High Oblique Images Taken by UAV }\end{array}$ & 2018 & $\begin{array}{l}\text { Journal of the Korean Society for Geospatial Information } \\
\text { Science }\end{array}$ \\
\hline 12 & $\begin{array}{l}\text { Accuracy Analysis of Cadastral Control Point and Parcel Boundary Point by Flight } \\
\text { Altitude Using UAV }\end{array}$ & 2018 & $\begin{array}{l}\text { Journal of the Korean Society of Surveying, Geodesy, } \\
\text { Photogrammetry and Cartography }\end{array}$ \\
\hline 13 & $\begin{array}{l}\text { Accuracy Assessment on the Stereoscope-based Digital Mapping Using Unmanned } \\
\text { Aircraft Vehicle Image }{ }^{(19)}\end{array}$ & 2018 & Journal of Cadastre \& Land InformatiX \\
\hline 14 & $\begin{array}{l}\text { Location Accuracy of Unmanned Aerial Photogrammetry Results According to } \\
\text { Change of Number of Ground Control Points }{ }^{(20)}\end{array}$ & 2018 & $\begin{array}{l}\text { Journal of the Korean Association of Geographic } \\
\text { Information Studies }\end{array}$ \\
\hline 15 & Analysis of Low-Cost UAV Image Using Image Enhancement Methods ${ }^{(5)}$ & 2017 & $\begin{array}{l}\text { Journal of the Korean Society for Geospatial Information } \\
\text { Science }\end{array}$ \\
\hline 16 & $\begin{array}{l}\text { Accuracy and Economic Evaluation for Utilization of National/Public Land Actual } \\
\text { Condition Survey Using UAV Images }{ }^{(21)}\end{array}$ & 2017 & $\begin{array}{l}\text { Journal of the Korean Society of Surveying, Geodesy, } \\
\text { Photogrammetry and Cartography }\end{array}$ \\
\hline 17 & $\begin{array}{l}\text { High-Resolution and High-Definition Image Acquisition Using UAV and High- } \\
\text { Precision Aerial Triangulation }^{(22)}\end{array}$ & 2017 & $\begin{array}{l}\text { Journal of the Korean Society for Geospatial Information } \\
\text { Science }\end{array}$ \\
\hline 18 & $\begin{array}{l}\text { Accuracy Assessment of Parcel Boundary Surveying with a Fixed-wing UAV } \\
\text { versus Rotary-wing UAV }{ }^{(23)}\end{array}$ & 2017 & $\begin{array}{l}\text { Journal of the Korean Society of Surveying, Geodesy, } \\
\text { Photogrammetry and Cartography }\end{array}$ \\
\hline 19 & Application of UAV Photogrammetry for Standardization of Shoreline Survey ${ }^{(24)}$ & 2017 & $\begin{array}{l}\text { Asia-Pacific Journal of Multimedia Services Convergent } \\
\text { with Art, Humanities, and Sociology }\end{array}$ \\
\hline 20 & $\begin{array}{l}\text { Comparison of Orthophoto and 3D Modeling Using Vertical and High Oblique } \\
\text { Images taken by UAV }\end{array}$ & 2017 & $\begin{array}{l}\text { Journal of the Korean Society for Geospatial Information } \\
\text { Science }\end{array}$ \\
\hline 21 & $\begin{array}{l}\text { Orthophoto and DEM Generation Using Low Specification UAV Images from } \\
\text { Different Altitudes }{ }^{(4)}\end{array}$ & 2016 & $\begin{array}{l}\text { Journal of the Korean Society of Surveying, Geodesy, } \\
\text { Photogrammetry and Cartography }\end{array}$ \\
\hline 22 & $\begin{array}{l}\text { Quality Evaluation of Orthoimage and DSM Based on Fixed-Wing UAV } \\
\text { Corresponding to Overlap and GCPs }\end{array}$ & 2016 & $\begin{array}{l}\text { Journal of the Korean Society for Geospatial Information } \\
\text { Science }\end{array}$ \\
\hline 23 & $\begin{array}{l}\text { Building of 3D Terrain Modeling and Evaluation of Location Accuracy Using UAV } \\
\text { in Beach Area }{ }^{(26)}\end{array}$ & 2016 & Journal of the Korean Cadastre Information Association \\
\hline 24 & $\begin{array}{l}\text { Damage Analysis and Accuracy Assessment for River-side Facilities using UAV } \\
\text { Images }{ }^{(27)}\end{array}$ & 2016 & $\begin{array}{l}\text { Journal of the Korean Society for Geospatial Information } \\
\text { Science }\end{array}$ \\
\hline 25 & Accuracy Analysis of Coastal Area Modeling through UAV Photogrammetry $(28)$ & 2016 & Korean Journal of Remote Sensing \\
\hline 26 & $\begin{array}{l}\text { Availability Evaluation For Generation Orthoimage Using Photogrammetric UAV } \\
\text { System }^{(6)}\end{array}$ & 2016 & Korean Journal of Remote Sensing \\
\hline 27 & $\begin{array}{l}\text { Accuracy of Parcel Boundary Demarcation in Agricultural Area Using UAV- } \\
\text { Photogrammetry }{ }^{(29)}\end{array}$ & 2016 & $\begin{array}{l}\text { Journal of the Korean Society of Surveying, Geodesy, } \\
\text { Photogrammetry and Cartography }\end{array}$ \\
\hline 28 & Lane Extraction through UAV Mapping and Its Accuracy Assessment ${ }^{(3)}$ & 2016 & $\begin{array}{l}\text { Journal of the Korean Society of Surveying, Geodesy, } \\
\text { Photogrammetry and Cartography }\end{array}$ \\
\hline 29 & $\begin{array}{l}\text { Orthophoto and DEM Generation in Small Slope Areas Using Low Specification } \\
\text { UAV }^{(30)}\end{array}$ & 2016 & $\begin{array}{l}\text { Journal of the Korean Society of Surveying, Geodesy, } \\
\text { Photogrammetry and Cartography }\end{array}$ \\
\hline 30 & Accuracy Analysis of UAV Data Processing Using DPW ${ }^{(31)}$ & 2015 & $\begin{array}{l}\text { Journal of the Korean Society for Geospatial Information } \\
\text { Science }\end{array}$ \\
\hline 31 & $\begin{array}{l}\text { Analysis of the Spatial Information Accuracy According to Photographing } \\
\text { Direction of Fixed Wing UAV }{ }^{(32)}\end{array}$ & 2015 & Journal of the Korean Cadastre Information Association \\
\hline 32 & $\begin{array}{l}\text { Availability Evaluation of UAV for Construction of Geospatial Information about } \\
\text { Quantity }{ }^{33)}\end{array}$ & 2014 & nal of the Korean Cadastre Information Association \\
\hline 33 & A Study on the Application of UAV for Korean Land Monitoring ${ }^{(34)}$ & 2014 & $\begin{array}{l}\text { Journal of the Korean Society of Surveying, Geodesy, } \\
\text { Photogrammetry and Cartography }\end{array}$ \\
\hline 34 & $\begin{array}{l}\text { Availability Evaluation for Generation of Geospatial Information Using Fixed } \\
\text { Wing } U^{(35)}\end{array}$ & 2014 & $\begin{array}{l}\text { Journal of the Korean Society for Geospatial Information } \\
\text { System }\end{array}$ \\
\hline
\end{tabular}




\section{Meta-analysis and Statistical Analysis of the Accuracy}

\subsection{Meta-analysis}

Meta-analysis is a statistical method of synthesizing a pooled estimate by combining estimates from two or more individual studies. In other words, it is a statistical technique used to quantitatively estimate an integrated summary of estimates of the results presented in the studies and to evaluate effectiveness and efficiency. ${ }^{(36)}$ In this study, the accuracy of UAVs is classified into horizontal and vertical accuracies, and their relation with flight altitude is analyzed.

The effect size is a quantitative index used to summarize the results of the study in a metaanalysis. ${ }^{(37)}$ The effect size can be used to give a specific figure for relevance. A method of estimating the effect size using a correlation coefficient was used. The formula used is as follows. ${ }^{(38)}$

$$
z=\frac{1}{2} \log \left(\frac{1+r}{1-r}\right)
$$

$z$ : Z-transformed sample correlation coefficient, $r$ : sample correlation coefficient

The Z-transformation of the number of model relations corresponding to the Z-transformation of the sample correlation coefficient is as follows.

$$
\boldsymbol{\varsigma}=\frac{1}{2} \log \left(\frac{1+\rho}{1-\rho}\right)
$$

$\rho$ : correlation coefficient

The Z-transformed values of the correlation coefficients generally follow the normal distribution, and the uncertainty of the sampling of the Z-transformed correlation coefficients can also be expressed using the following dispersion formula.

$$
\boldsymbol{V}=\frac{1}{n-3}
$$

$n$ : number of samples in the study

In this study, flight altitude, horizontal accuracy, vertical accuracy, minimum value, maximum value, and variance were used to analyze the correlation between flight altitude and accuracy. Meta-analysis was performed using the R statistical website. Table 2 shows the data used for effect size analysis and Figs. 2 and 3 show forest plots for horizontal and vertical accuracies, respectively.

As shown in Figs. 2 and 3, the effect sizes of horizontal and vertical accuracies and flight altitude are 1.2 and 1.07, respectively. Therefore, in this study, statistical analysis was 
Table 2

Data for effect size analysis.

\begin{tabular}{|c|c|c|c|c|c|c|c|c|c|}
\hline \multirow{2}{*}{ Study } & \multicolumn{4}{|c|}{ Horizontal (m) } & \multirow{2}{*}{ Study } & \multicolumn{4}{|c|}{ Vertical (m) } \\
\hline & Accuracy & Minimum & Maximum & Variance & & Accuracy & Minimum & Maximum & Variance \\
\hline Study2 & 0.059 & 0.019 & 0.086 & 0.00100 & Studyl & 0.042 & 0.016 & 0.074 & 0.00059 \\
\hline Study3 & 0.041 & 0.021 & 0.073 & 0.00000 & Study2 & 0.013 & -0.013 & 0.026 & 0.00061 \\
\hline Study4 & 0.040 & 0.007 & 0.129 & 0.00600 & Study3 & 0.075 & 0.051 & 0.095 & 0.00029 \\
\hline Study5 & 0.090 & 0.036 & 0.147 & 0.00300 & Study4 & 0.040 & -0.120 & 0.077 & 0.00339 \\
\hline Study6 & 0.052 & 0.004 & 0.095 & 0.00100 & Study5 & 0.059 & 0.008 & 0.124 & 0.00350 \\
\hline Study10 & 0.027 & 0.014 & 0.07 & 0.00000 & Study6 & 0.026 & -0.036 & 0.073 & 0.00106 \\
\hline Study11 & 0.045 & 0.00 & 0.122 & 0.00100 & Study8 & 0.222 & 0.146 & 0.257 & 0.00116 \\
\hline Study14 & 0.045 & 0.005 & 0.103 & 0.00100 & Study10 & 0.018 & -0.029 & 0.035 & 0.00043 \\
\hline Study15 & 0.050 & 0.00 & 0.092 & 0.00100 & Study11 & 0.053 & -0.266 & 0.083 & 0.00652 \\
\hline Study17 & 0.067 & 0.019 & 0.103 & 0.00000 & Study17 & 0.060 & -0.055 & 0.140 & 0.00446 \\
\hline Study20 & 0.082 & 0.01 & 0.23 & 0.00300 & Study20 & 0.093 & -0.280 & 0.130 & 0.01344 \\
\hline Study21 & 0.041 & 0.025 & 0.057 & 0.00000 & Study 22 & 0.038 & -0.071 & 0.069 & 0.00229 \\
\hline Study 22 & 0.015 & 0.005 & 0.026 & 0.00000 & Study24 & 0.022 & 0.011 & 0.055 & 0.00048 \\
\hline Study24 & 0.029 & 0.023 & 0.037 & 0.00000 & Study 25 & 0.040 & -0.081 & 0.189 & 0.00667 \\
\hline Study 25 & 0.063 & 0.012 & 0.129 & 0.00200 & Study26 & 0.039 & -0.104 & 0.052 & 0.00240 \\
\hline Study26 & 0.037 & 0.003 & 0.074 & 0.00100 & Study27 & 0.123 & 0.064 & 0.189 & 0.00161 \\
\hline$\vdots$ & $\vdots$ & $\vdots$ & $\vdots$ & $\vdots$ & $\vdots$ & $\vdots$ & $\vdots$ & $\vdots$ & \\
\hline
\end{tabular}

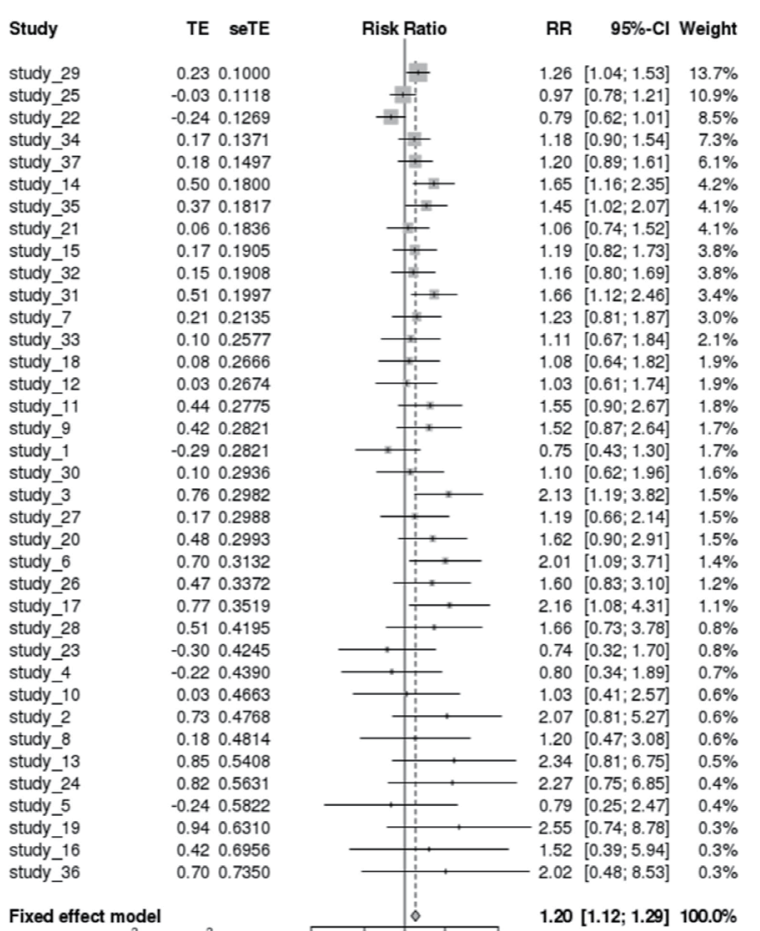

Fig. 2. Forest plot for horizontal accuracy.

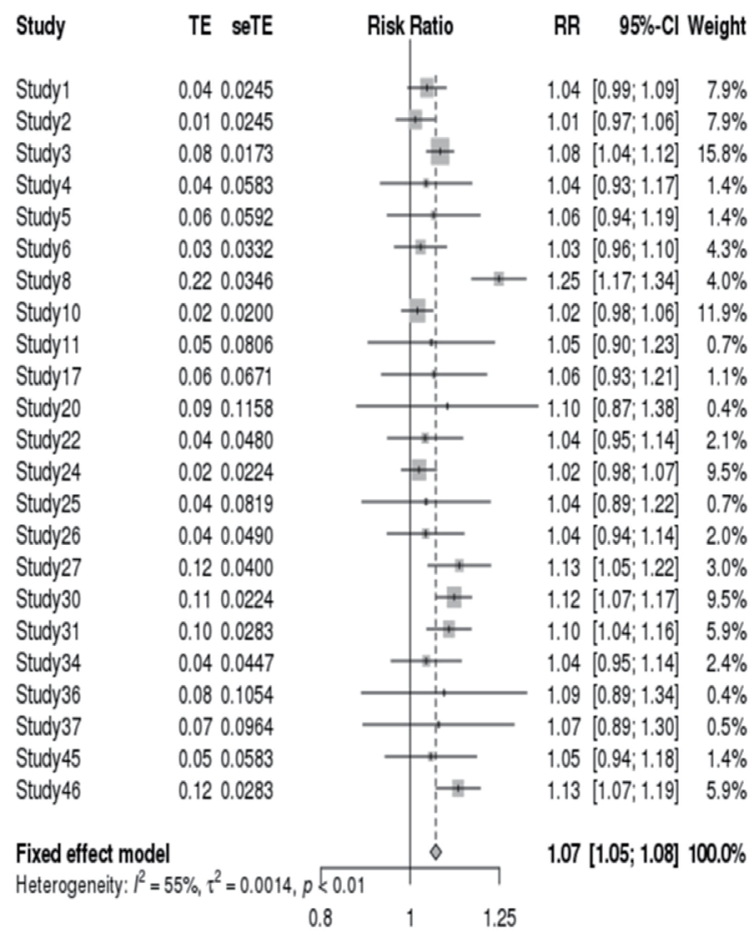

Fig. 3. Forest plot for vertical accuracy.

performed to show the general horizontal and vertical accuracies of geospatial information obtained by a UAV. Figures 4 and 5 show the fixed effect models for horizontal and vertical accuracies, respectively. 


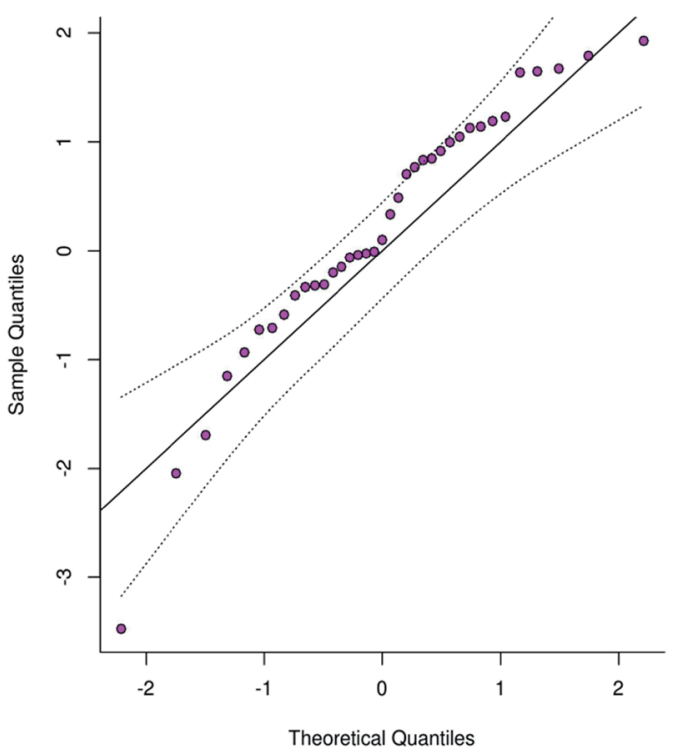

Fig. 4. (Color online) Fixed effect model of horizontal accuracy.

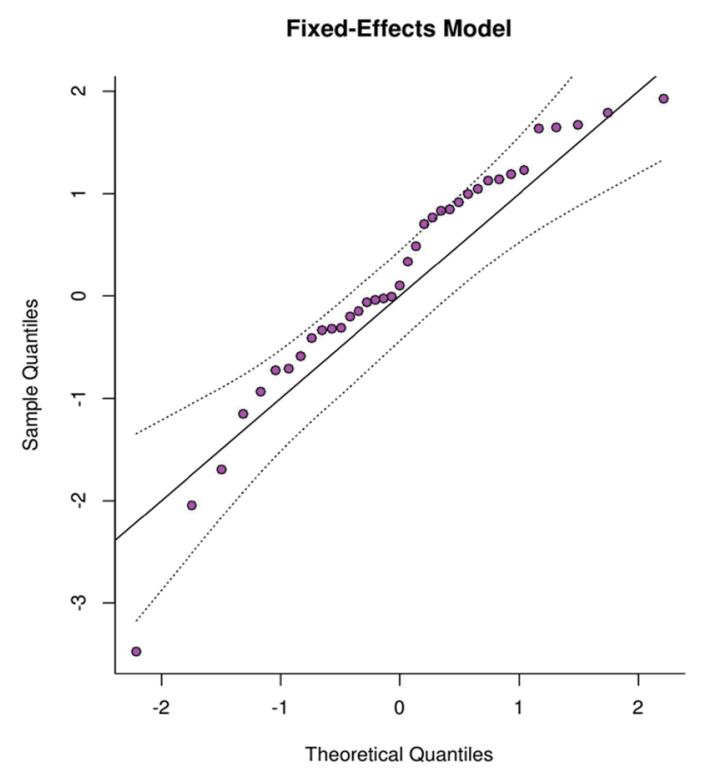

Fig. 5. (Color online) Fixed effect model of vertical accuracy.

\subsection{Statistical analysis}

In the previous studies, only the accuracy evaluation was performed under the experimental conditions of the individual studies, and the analysis of the relation between flight altitude, GSD, and accuracy was insufficient. In this study, the statistical analysis of flight altitude, GSD, and accuracy was performed for the integrated analysis of geospatial information constructed by unmanned aerial photogrammetry. Table 3 summarizes the results of previous studies analyzing the horizontal and vertical accuracies of geospatial information constructed by a UAV. The main summary items are horizontal and vertical accuracies, flight height, and ground control point (GCP) number.

The method of statistical analysis used is regression analysis, and the dependent variables are horizontal and vertical accuracies. The independent variables used are the flight altitude and GCP number. Table 4 shows the statistics for accuracy and Table 5 shows the correlation coefficients.

The horizontal accuracy of the geospatial information constructed using a UAV was $0.51 \mathrm{~m}$ on average and the vertical accuracy was $0.56 \mathrm{~cm}$ on average. Although the accuracy of a general UAV cannot be presented because of the different experimental conditions in the studies, the results of the research showed that the accuracy of geospatial information constructed by a UAV can be predicted. Also, as shown in Table 5, the horizontal and vertical accuracies are inversely proportional to the flight altitude and GCP number. It can be seen that the GCP number has a greater impact on accuracy than the flight altitude. Figures 6 and 7 show histograms of the dependent variables. Figure 8 shows the P-P plot for the horizontal accuracy and Fig. 9 shows the P-P plot for vertical accuracy. 
Table 3

Summary of the results of previous studies.

\begin{tabular}{lcccccc}
\hline Study & Height & GCP & H.Accuracy $(\mathrm{m})$ & H.RMSE $(\mathrm{m})$ & V $(\mathrm{m})$ & V.RMSE $(\mathrm{m})$ \\
\hline Study1 & 120 & 8 & - & - & 0.042 & 0.024 \\
Study2 & 80 & 6 & 0.059 & 0.025 & 0.013 & 0.016 \\
Study3 & 160 & 5 & 0.041 & 0.02 & 0.075 & 0.017 \\
Study4 & 30 & 6 & 0.04 & 0.04 & 0.04 & 0.058 \\
Study5 & 150 & 10 & 0.09 & 0.056 & 0.059 & 0.059 \\
Study6 & 50 & 4 & 0.052 & 0.03 & 0.026 & 0.032 \\
Study8 & 150 & 8 & - & - & 0.222 & 0.034 \\
Study10 & 150 & 9 & 0.027 & 0.018 & 0.018 & 0.021 \\
Study11 & 70 & 5 & 0.045 & 0.032 & 0.053 & 0.081 \\
Study12 & 50 & 3 & 0.036 & 0.028 & 0.047 & 0.026 \\
Study14 & 100 & 11 & 0.045 & 0.038 & - & - \\
Study15 & 210 & 15 & 0.05 & 0.028 & - & - \\
Study17 & 260 & 9 & 0.067 & 0.022 & 0.06 & 0.067 \\
$\vdots$ & $\vdots$ & $\vdots$ & $\vdots$ & $\vdots$ & $\vdots$ & $\vdots$ \\
\hline
\end{tabular}

Table 4

Summary of the results of previous studies.

\begin{tabular}{lccclccc}
\hline Item & Average $(\mathrm{m})$ & RMSE $(\mathrm{m})$ & $N$ & Item & Average $(\mathrm{m})$ & RMSE $(\mathrm{m})$ & $N$ \\
\hline H. Acc. & 0.05172 & 0.020904 & 32 & V. Acc. & 0.05992 & 0.043518 & 26 \\
Height & 139.78 & 66.143 & 32 & Height & 131.65 & 64.657 & 26 \\
GCP & 8.41 & 4.134 & 32 & GCP & 7.69 & 3.380 & 26 \\
\hline
\end{tabular}

Table 5

Correlation coefficients.

\begin{tabular}{|c|c|c|c|c|c|c|c|c|c|}
\hline Item & & H. Acc. & Height & GCP & Item & & V. Acc. & Height & GCP \\
\hline \multirow{3}{*}{$\begin{array}{l}\text { Significance } \\
\text { probability }\end{array}$} & H. Acc. & - & 0.259 & 0.105 & \multirow{3}{*}{$\begin{array}{l}\text { Significance } \\
\text { probability }\end{array}$} & H. Acc. & - & 0.334 & 0.173 \\
\hline & Height & 0.259 & - & 0.036 & & Height & 0.334 & - & 0.200 \\
\hline & $\overline{\mathrm{GCP}}$ & 0.105 & 0.036 & - & & GCP & 0.173 & 0.200 & - \\
\hline
\end{tabular}

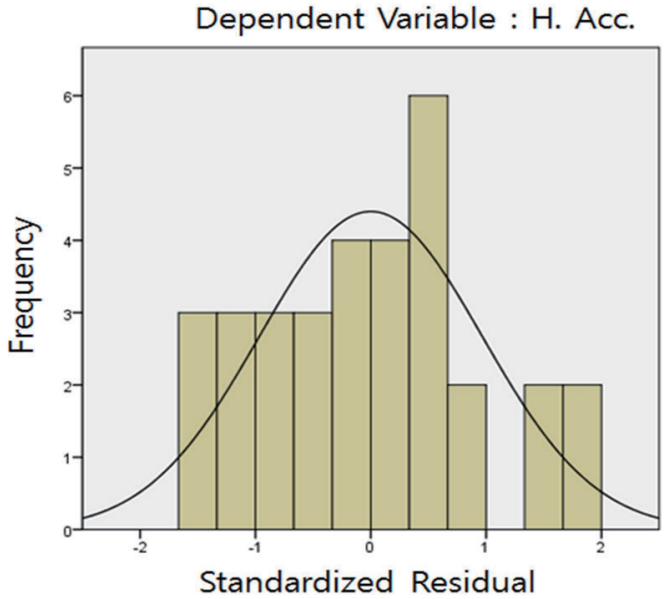

Fig. 6. (Color online) Histogram of horizontal accuracy.

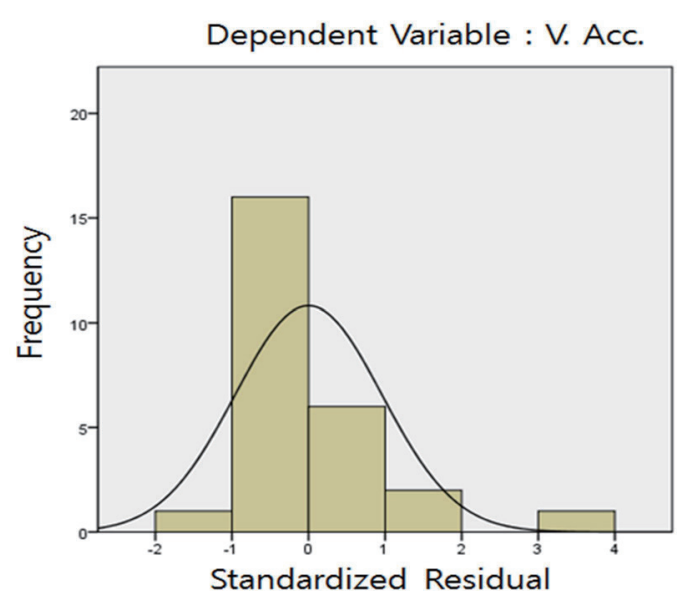

Fig. 7. (Color online) Histogram of vertical accuracy. 


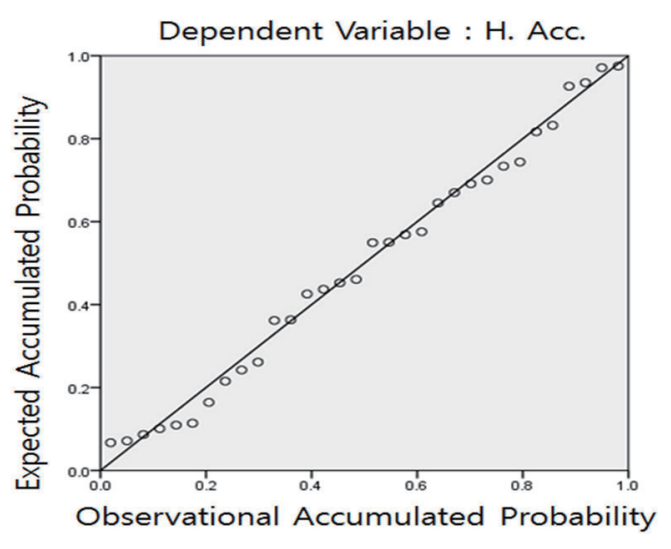

Fig. 8. P-P plot of horizontal accuracy.

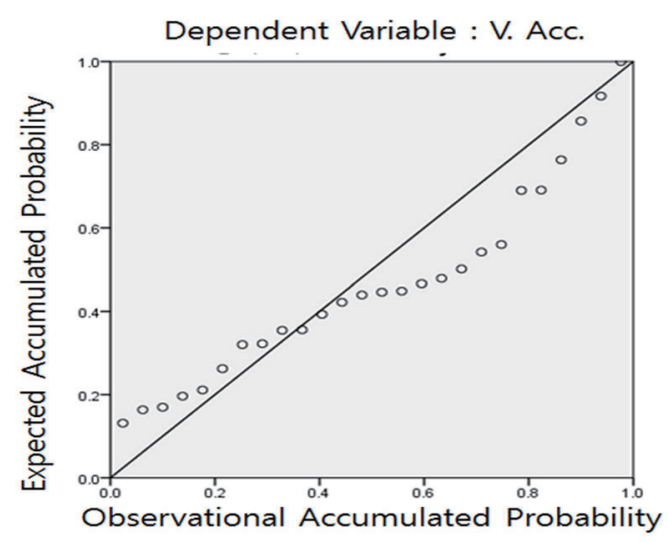

Fig. 9. P-P plot of vertical accuracy.

The accuracy of each dependent variable is affected by the number of flights and the GCP number. As shown in Figs. 4-7, the accuracy in the vertical direction appears to be less influenced by these effects. The results of this study show the accuracy of general UAV geospatial information through statistical analysis and will be used as a basis for examining the validity of geospatial information construction using a UAV in the future.

\section{Conclusions}

In this study, the validity of using a UAV for geospatial information construction was evaluated, and recent case studies related to the accuracy of the results were analyzed. The results of this study are as follows.

1. The results of 34 studies including the quantitative results of UAV accuracy within the last 5 years were investigated and the correlation of the flight altitude, accuracy, and GCP number was presented through analyses of these studies.

2. The horizontal and vertical accuracies of the terrain information obtained using UAVs were $0.51 \mathrm{~m}$ and $0.56 \mathrm{~cm}$, respectively. The horizontal and vertical accuracies were correlated with the flight altitude and GCP number. In particular, flight altitude had a greater effect than the GCP number.

3. In all case studies, the vertical accuracy of the UAV was lower than the horizontal accuracy.

4. In the future, the results of this study will be used as a basis for examining the validity of geospatial information construction using a UAV.

\section{Acknowledgments}

This research was supported by the Basic Science Research Program through the National Research Foundation of Korea (NRF) funded by the Ministry of Science and ICT (No. NRF2018R1C1B6004021). 


\section{References}

1 M. G. Kim and J. K. Park: J. Korea Acad.-Ind. Coop. Soc. 16 (2015) 697. https://doi.org/10.5762/ KAIS.2015.16.1.697

2 K. R. Lee and W. H. Lee: J. Korean Soc. Geospatial Inf. Sci. 25 (2017) 35. https://doi.org/10.7319/ kogsis.2017.25.4.035

3 C. H. Park, K. A. Choi, and I. P. Lee: J. Korean Soc. Surv. Geod. Photogramm. Cartography 34 (2016) 11. https://doi.org/ 10.7848/ksgpc.2016.34.1.11

4 K. R. Lee and W. H. Lee: J. Korean Soc. Surv. Geod. Photogramm. Cartography 34 (2016) 535. https://doi.org/ 10.7848/ 10.7848/ksgpc.2016.34.5.535

5 J. H. Sung and W. H. Lee: J. Korean Soc. Geospatial Inf. Sci. 25 (2017) 3. https://doi.org/10.7319/ kogsis.2017.25.3.003

6 D. Y. Shin, J. H. Han, Y. J. Jin, J. Y. Park, and H. H. Jeong: Korean J. Remote Sens. 32 (2016) 275. https://doi. org/ 10.7780/kjrs.2016.32.3.7

7 J. K. Park and D. Y. Um: J. Korea Acad.-Ind. Coop. Soc. 19 (2018) 155. https://doi.org/10.5762/ KAIS.2018.19.3.155

8 M. S. Do, E. T. Lim, J. H. Chae, and S. H. Kim: J. Korea Inst. Intell. Transp. Syst. 17 (2018) 117. https://doi. org/ 10.12815/kits.2018.17.5.117

9 J. U. Kim, W. H. Lee, and H. S. Shin: J. Korean Inst. Traditional Landscape Archit. 36 (2018) 97. https://doi. org/10.14700/KITLA.2018.36.1.097

10 S. B. Lim, C. W. Seo, and H. C. Yun: J. Korean Soc. Surv. Geod. Photogramm. Cartography 33 (2015) 397. https://doi.org/ 10.7848/ksgpc.2015.33.5.397

11 J. O. Lee and S. M. Sung: J. Korea Acad.-Ind. Coop. Soc. 19 (2018) 63. https://doi.org/10.5762/ KAIS.2018.19.4.63

12 M. C. Kim and H. J. Yoon: J. Korea Acad.-Ind. Coop. Soc. 19 (2018) 97. https://doi.org/10.5762/ KAIS.2018.19.2.97

13 B. G. Lee: J. Korean Earth Sci. Soc. 39 (2018) 46. https://doi.org/ 10.5467/JKESS.2018.39.1.46

14 T. W. Kim, S. H. Hong, H. Choi, and K. H. Lee: J. Korean Soc. Geospatial Inf. Sci. 26 (2018) 69. https://doi. org/10.7319/kogsis.2018.26.1.069

15 S. U. Lee, D. Y. Mun, J. W. Seong, and J. W. Kim: J. Korean Assoc. Geographic Inf. Studies 21 (2018) 127. https://doi.org/10.11108/kagis.2018.21.3.127

16 Y. D. Kim, B. W. Park, and H. S. Lee: J. Korean Soc. Geospatial Inf. Sci. 26 (2018) 31. https://doi.org/10.7319/ kogsis.2018.26.3.031

17 K. R. Lee, Y. K. Han, and W. H. Lee: J. Korean Soc. Geospatial Inf. Sci. 26 (2018) 23. https://doi.org/10.7319/ kogsis.2018.26.3.023

18 J. H. Kim and J. H. Kim: J. Korean Soc. Surv. Geod. Photogramm. Cartography 36 (2018) 223. https://doi. org/10.7848/ksgpc.2018.36.4.223

19 K. H. Yun, D. I. Kim, and Y. S. Song: J. Cadastre Land InformatiX 48 (2018) 111. https://doi.org/10.22640/ 1xsiri.2018.48.1.11

20 B. Y. Yun and S. M. Sung: J. Korean Assoc. Geographic Inf. Studies 21 (2018) 24. https://doi.org/10.11108/ kagis.2018.21.2.024

21 S. C. Lee, J. H. Kim, and J. S. Um: J. Korean Soc. Surv. Geod. Photogramm. Cartography 35 (2017) 175. https://doi.org/10.7848/ksgpc.2017.35.3.175

22 S. H. Han: J. Korean Soc. Geospatial Inf. Sci. 25 (2017) 101. https://doi.org/10.7319/kogsis.2017.25.3.101

23 S. M. Sung and J. W. Lee: J. Korean Soc. Surv. Geod. Photogramm. Cartography 35 (2017) 535. https://doi. org/10.7848/ksgpc.2017.35.6.535

24 M. G. Kim and K. Y. Jung: Asia-Pacific J. Multimedia Services Converg. Art Humanities Sociology 7 (2017) 953. https://doi.org/10.14257/ajmahs.2017.05.89

25 Y. H. Yoo, J. W. Choi, S. K. Choi, and S. H. Jung: J. Korean Soc. Geospatial Inf. Sci. 24 (2016) 3. https://doi. org $/ 10.7319 /$ kogsis.2016.24.3.003

26 K. S. Lee, Y. W. Choi, and J. J. Lee: J. Korean Cadastre Inf. Assoc. 18 (2016) 207.

27 M. C. Kim, H. J. Yoon, H. J. Chang, and J. S. Yoo: J. Korean Soc. Geospatial Inf. Sci. 24 (2016) 81. https://doi. org $/ 10.7319 /$ kogsis.2016.24.1.081

28 K. A. Choi and I. P. Lee: Korean J. Remote Sens. 32 (2016) 657. https://doi.org/10.7780/kjrs.2016.32.6.10

29 S. M. Sung and J. W. Lee: J. Korean Soc. Surv. Geod. Photogramm. Cartography 34 (2016) 53. https://doi. org/10.7848/ksgpc.2016.34.1.53 
30 J. H. Park and W. H. Lee: J. Korean Soc. Surv. Geod. Photogramm. Cartography 34 (2016) 283. https://doi. org/10.7848/ksgpc.2016.34.3.283

31 Y. W. Choi, J. H. You, and G. S. Cho: J. Korean Soc. Geospatial Inf. Sci. 23 (2015) 3. https://doi.org/10.7319/ kogsis.2015.23.4.003

32 G. S. Lee, Y. W. Choi, K. S. Jung, and G. S. Cho: J. Korean Cadastre Inf. Assoc. 17 (2015) 141.

33 I. H. Choi and M. G. Kim: J. Korean Cadastre Inf. Assoc. 16 (2014) 149.

34 D. I. Kim, Y. S. Song, G. H. Kim, and C. W. Kim: J. Korean Soc. Surv. Geod. Photogramm. Cartography 32 (2014) 29. https://doi.org/10.7848/ksgpc.2014.32.1.29

35 Y. J. Park and K. Y. Jung: J. Korean Soc. Geospatial Inf. Syst. 22 (2014) 159. https://doi.org/10.7319/ kogsis.2014.22.4.159

36 J. S. Bae, J. Y. Kwon, and S. B. Nam: Korean J. Phys. Edu. 57 (2018) 235.

37 M. S. Shin: J. Korean Assoc. Learner-centered Curriculum Instruction 18 (2018) 471.

38 J. P. Baek: J. Korean Assoc. Learner-centered Curriculum Instruction 18 (2018) 689. https://doi.org/10.22251/ jlcci.2018.18.15.689

\section{About the Authors}

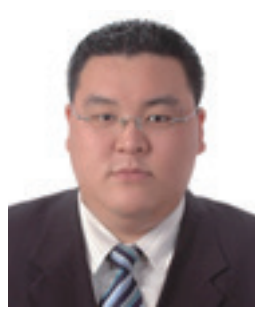

Joon Kyu Park is currently a professor in the Department of Civil Engineering at Seoil University. He received his B.S., M.S., and Ph.D. degrees in civil engineering from Chungnam National University, Korea, in 2001, 2003, and 2008, respectively. His research interests are in the areas of GPS and geo-spatial information engineering. (jkpark@seoil.ac.kr)

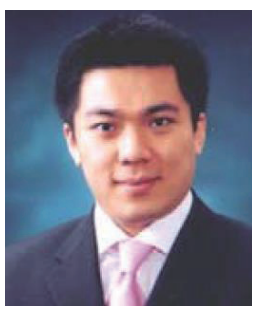

Kap Yong Jung is currently a professor in the Department of Construction Engineering Education at Chungnam National University. He received his B.S., M.S., and Ph.D. degrees in civil engineering from Chungnam National University, Korea, in 2003, 2009, and 2013, respectively. His research interests are in the areas of geodetic science and geo-spatial information. (jungjusa@hanmail.net)

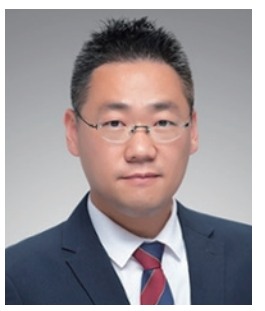

Joong Hyeok Heo is currently a professor in the Department of Geosciences Geology at University of Texas Permian Basin. He received his Ph.D. degree in geology and geophysics from Texas A\&M University and his M.S. degree in earth and environmental sciences from Seoul National University. His research interests are in the areas of hydrology, modeling investigation, environmental geochemistry, and engineering geology. (heo_j@utpb.edu) 